\title{
Effect of cyclosporin A particles of varying diameters on gastric cancer cell apoptosis
}

\author{
X.L. Xing ${ }^{1}$, Y. Lu ${ }^{2}$ and H.L. Qiu ${ }^{1}$ \\ ${ }^{1}$ Pharmacy Intravenous Admixture Room, Binzhou People's Hospital, \\ Shandong, China \\ ${ }^{2}$ Operating Room, Binzhou People's Hospital, Shandong, China \\ Corresponding author: X.L. Xing \\ E-mail: xx1150608@163.com
}

Genet. Mol. Res. 15 (2): gmr.15028085

Received November 18, 2015

Accepted January 5, 2016

Published April 25, 2016

DOI http://dx.doi.org/10.4238/gmr.15028085

\begin{abstract}
Human health is significantly threatened by gastric cancer, which is the most common malignant tumor; although drastic, surgery is currently the only way to cure it. However, high recurrence rates and low survival rates are associated with the disease. Therefore, to improve the effectiveness of gastric cancer treatment and to increase the clinical cure rate, we investigated the effect of cyclosporin A particles of varying diameter on gastric cancer cell apoptosis. Flow cytometry was used to detect apoptosis induced by Annexin V-fluorescein isothiocyanate/ propidium iodide-double labeling. We also determined the content of reactive oxygen species and the expression level of P-glycoprotein in cells after treatment with cyclosporin $\mathrm{A}$. The results indicated that increases in the concentration and action time of cyclosporin A were associated with statistically significant increases in the apoptosis rate of gastric cancer cells when the experimental and control groups were compared $(\mathrm{P}<$ 0.05 and $\mathrm{P}<0.01$, respectively). In conclusion, during a certain action time and concentration range, cyclosporin $\mathrm{A}$ inhibits the proliferation of human gastric cancer cells and can induce their apoptosis.
\end{abstract}

Key words: Cell apoptosis; Cyclosporin A; Gastric cancer; Expression level 


\section{INTRODUCTION}

Gastric cancer is currently one of the most common malignant tumors (Miki et al., 2007). It is associated with considerably high incidence and death rates, and is considered the second most dangerous form of cancer. Surgical operation or postoperative chemotherapy are the standard therapies approved globally for patients suffering from gastric cancer. However, the inherent or acquired multi-drug resistance (MDR) (Diestra et al., 2002) of tumors is the main cause of the unsatisfactory therapeutic effects of chemotherapeutic drugs on gastric cancer. Cyclosporin A (CsA) is a first-generation MDR reversal agent (Slattery et al., 2005), and it can inhibit the expression of P-glycoprotein (P-gp). It also has a satisfactory anti-tumor effect on gastric cancer when combined with other chemotherapeutic drugs.

In recent years, many researchers have carried out relevant studies on the anti-tumor effect of CsA. For instance, Xiao et al. (2011) reported variable results for the effect of CsA on cell apoptosis: CsA induced apoptosis in some kinds of cell, but inhibited it in others. Grodzicky and Elkon (2000) studied the composition, preparation, pharmaceutical characteristics, internal pharmacokinetics, and anaphylactic reaction effects of CsA-loaded $\mathrm{pH}$-sensitive nanoparticles. The pharmaceutical, internal pharmacokinetic, and anaphylactic reaction properties of the nanoparticles after freeze-drying were also studied. Wang and Zhang (2001) indicated that CsA was a powerful new type of immunosuppressant with advantages such as high selectivity, relatively low toxicity, few side effects, and low infection risk, compared with traditional immunosuppressants. Wu et al. (2013) proposed that, as well as inhibiting the ability of T cells to regulate the immune response by interfering with intracellular signal transduction, CsA could intervene at every stage of somatic cell apoptosis to inhibit it. Moreover, they reported that CsA was dose-dependent and participated in the proliferation and differentiation of cells through different signal pathways.

Therefore, in this study we chose to determine the effect of CsA on P-gp expression in human gastric cancer cells. We also studied the ability of CsA to inhibit proliferation and induce apoptosis in gastric cancer cells. Our hope is that our results will have scientific value for assessing CsA's anti-cancer effect on gastric cancer in clinical practice.

\section{MATERIAL AND METHODS}

\section{Materials and instruments}

Human gastric cancer cells were purchased from Beijing Yuan Tang Shengxing Science and Technology Co., Ltd. (Beijing, China), and standard CsA was directly purchased from Shanghai Jiang Lai Biotechnology Co., Ltd. (Shanghai, China). The main instruments used in this study were an electrophoresis tank, a transfer tank, an LD4-8 low-speed centrifuge, a refrigerator set at $-80^{\circ} \mathrm{C}$, and an ELX800UV microplate reader.

\section{Cell grouping}

CsA was used to act on human gastric cancer cells. Gastric cancer cells in the logarithmic phase (Ishizaki et al., 2001) were selected. CsA was used at concentrations of $0,5.0,10.0,15.0,20.0$, and $25.0 \mu \mathrm{M}$. The duration of CsA cell treatment was determined according to the specific experimental requirements. 


\section{Cell processing}

Three to five generations of gastric cancer cells were cultured in a culture flask $(5 \mathrm{x}$ $10^{5}$ cells $/ \mathrm{mL}$ ). The cells became attached during overnight incubation. They were then washed twice in phosphate-buffered saline (PBS) solution, and fresh culture medium containing 10\% fetal bovine serum was added to the culture flask for continuous culture (Sotiropoulou et al., 2006). When confluence exceeded $60 \%$ and the cells were growing well, CsA was added to the culture flask. However, the concentration of CsA and the duration of culture were determined by actual experimental requirements.

\section{Measurement of cell apoptosis rate}

Gastric cancer cells in the logarithmic phase were inoculated on a culture plate. After a night, CsA (concentrations in 5.0, 15.0 and $25.0 \mu \mathrm{M}$ ) was added; cells were continuously cultured for 2 days and then $0.25 \%$ cell digestive solution was used to digest cells (Takeda et al., 1966). The number of cells in each group was adjusted to $1.2 \times 10^{6}-5.2 \times 10^{6}$ cells $/ \mathrm{mL}$. The cells were centrifuged for $5 \mathrm{~min}$ and then the culture medium was removed. The cells were then washed twice in PBS solution and centrifuged again at $2000 \mathrm{rpm}$ for $5 \mathrm{~min} ; 400 \mu \mathrm{L}$ buffer solution was added to resuspend the cells. Annexin V-fluorescein isothiocyanate $(5 \mu \mathrm{L})$ was then added. After mixing, $5 \mu \mathrm{L}$ propidium iodide was added. The cells were incubated in the dark at room temperature for $15 \mathrm{~min}$. After $1 \mathrm{~h}$, flow cytometry was used to determine the apoptosis rate of the cells. The whole process was repeated three times to calculate the average apoptosis rate of the cells after $48 \mathrm{~h}$ of CsA treatment.

\section{Extraction of protein samples}

The culture medium was discarded and the culture flasks were placed upside-down on a filter paper to absorb the excess culture medium. PBS solution, which was precooled to $4^{\circ} \mathrm{C}$, was added to each culture flask $(2 \mathrm{~mL} ; 0.01 \mathrm{M} ; \mathrm{pH}$ 7.2-7.3). The flasks were gently agitated for $1 \mathrm{~min}$ to wash the cells and the washing liquor was removed. The whole process was repeated twice. The culture flasks were then placed on ice. The lysis solution and phenylmethanesulfonyl fluoride (PMSF) were mixed; every $1 \mathrm{~mL}$ lysis solution was mixed with $10 \mu \mathrm{L}$ PMSF. After thorough mixing, the flask that contained the mixture of lysis solution and PMSF was put on ice. The lysis solution and PMSF mixture $(150 \mu \mathrm{L})$ was added to each culture flask to achieve full lysis of the cells; the culture flasks were then placed on a shaking bed on ice for $30 \mathrm{~min}$ to split the cells. The cells were scraped together using a clean scraper immediately after cell lysis, and the cell debris and lysis solution were transferred to a $1.5-\mathrm{mL}$ centrifuge tube using a pipette. The collected cell lysis solution was centrifuged at $2000 \mathrm{rpm}$ for $5 \mathrm{~min}$ at $4^{\circ} \mathrm{C}$, and the supernatant liquid was transferred to a $0.5-\mathrm{mL}$ centrifuge tube and kept at $-20^{\circ} \mathrm{C}$.

\section{Protein quantification measurement}

\section{Drawing of the standard curve}

Bovine serum albumin $(1 \mathrm{mg} / \mathrm{mL})$ that had been stored in a refrigerator at $-20^{\circ} \mathrm{C}$ was 
taken out and melted at room temperature. Eighteen $1.5-\mathrm{mL}$ centrifuge tubes were divided into six groups (three tubes per group); each tube was marked as 0, 2.5, 5.0, 7.5, 10.0, and $20.0 \mu \mathrm{g}$, and different reagents were added to each tube, as shown in Table 1.

Table 1. Reagent composition added to each centrifuge tube.
\begin{tabular}{|l|c|c|c|c|c|c}
\hline Tube & $0 \mu \mathrm{g}$ & $2.5 \mu \mathrm{g}$ & $5.0 \mu \mathrm{g}$ & $7.5 \mu \mathrm{g}$ & $10.0 \mu \mathrm{g}$ & $20.0 \mu \mathrm{g}$ \\
\hline $\mathrm{BSA}(1 \mathrm{mg} / \mathrm{mL})$ & - & $2.5 \mu \mathrm{g}$ & $5.0 \mu \mathrm{g}$ & $7.5 \mu \mathrm{g}$ & $10.0 \mu \mathrm{g}$ & $20.0 \mu \mathrm{g}$ \\
\hline $\mathrm{NaCl}(0.15 \mathrm{M})$ & $100 \mu \mathrm{g}$ & $95 \mu \mathrm{g}$ & $90 \mu \mathrm{g}$ & $85 \mu \mathrm{g}$ & $80 \mu \mathrm{g}$ & $70 \mu \mathrm{g}$ \\
\hline Coomassie brilliant blue solution $(\mathrm{G} 250)$ & $1.5 \mathrm{~mL}$ & $1.5 \mathrm{~mL}$ & $1.5 \mathrm{~mL}$ & $1.5 \mathrm{~mL}$ & $1.5 \mathrm{~mL}$ & $1.5 \mathrm{~mL}$ \\
\hline $\mathrm{BSA}=$ bovine serum albumin.
\end{tabular}

\section{Measurement of protein content}

Coomassie brilliant blue (CBB) solution was added to the $1.5-\mathrm{mL}$ centrifuge tubes. The tubes were left at room temperature for $30 \mathrm{~min}$ and the protein content was then measured. A volume of $\mathrm{NaCl}$ solution $(100 \mu \mathrm{L} ; 0.15 \mathrm{M})$ was added to the $\mathrm{CBB}$ solution in each tube, and the reagents were thoroughly mixed. After $2 \mathrm{~min}$, the mixed solution was ready for use as a blank sample; the blank sample was transferred to a cuvette. After the standard curve had been produced, the "Blank" button was pressed to analyze the blank sample. The blank sample was then discarded, and the cuvette was washed twice with absolute ethyl alcohol and once with sterile water. A volume of $\mathrm{NaCl}$ solution $(90 \mu \mathrm{L} ; 0.15$ $\mathrm{M})$ and the protein samples to be tested $(5 \mu \mathrm{L})$ were added to the CBB solution in each tube. The mixed solution was thoroughly mixed and put aside for $2 \mathrm{~min}$. The obtained solution was then transferred to a clean, dry cuvette and the "Sample" button was pressed to analyze the sample.

\section{Statistical methods}

All experiments were repeated three times to calculate the results. The final experimental data are reported as means \pm SD. One-way analysis of variance (ANOVA) between the experimental groups and the control group was processed using the SPSS v.17.0 software. Correlation between two factors was assessed by Pearson correlation analysis. Statistical significance was evaluated at $\mathrm{P}<0.05$ and $\mathrm{P}<0.01$.

\section{RESULTS}

\section{Influence of CsA on cell apoptosis}

The results showed that after $48 \mathrm{~h}$ of treatment with CsA at different concentrations (5.0, 15.0, and $25.0 \mu \mathrm{M})$, gastric cancer cells presented different degrees of apoptosis. Moreover, the apoptosis rates of the cells increased with the increase of CsA concentration, and there was an obvious dose-effect relationship. The experiments were repeated three times. There were statistically significant differences between the rates of apoptosis induced by treatment with CsA at 15.0 and $25.0 \mu \mathrm{M}$ in the gastric cancer cells compared with the rate in the control group $(\mathrm{P}<0.05, \mathrm{P}<0.01$; Figure 1$)$. 


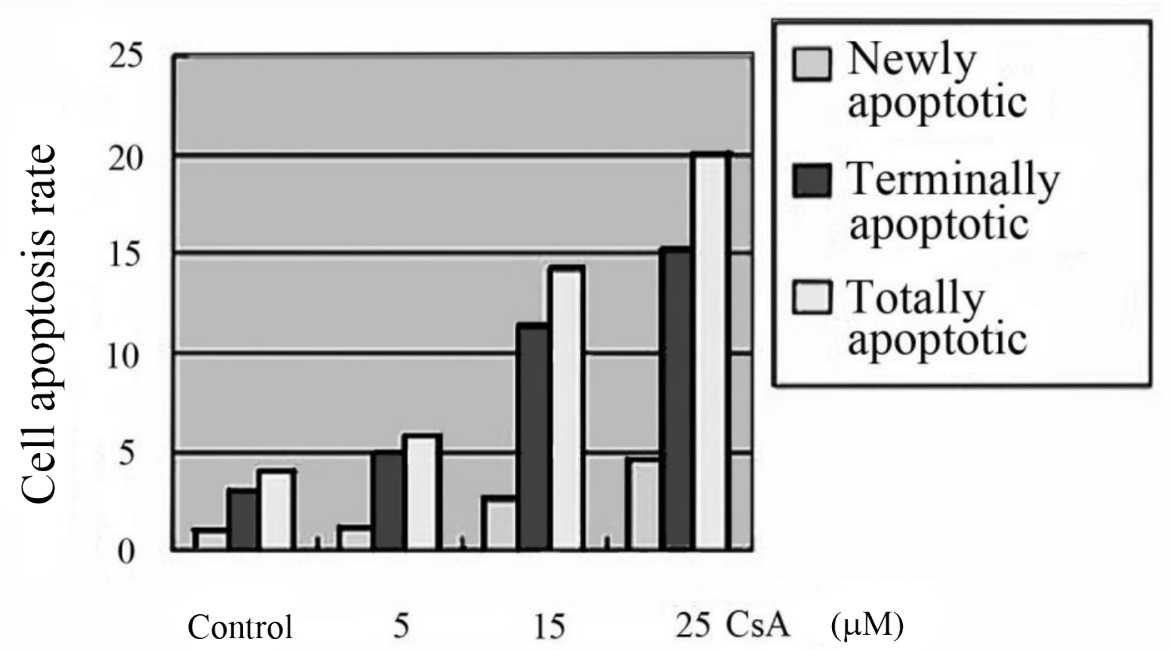

Figure 1. Rates of apoptosis induced by different concentrations of cyclosporin A (CsA) in gastric cancer cells.

\section{Influence of CsA on expression of P-gp in cells}

P-gp is usually expressed in cancer cells, especially gastric cancer cells, and is sometimes highly expressed. In this study, the results showed that after $48 \mathrm{~h}$ of treatment with CsA at concentrations of 5.0-40.0 $\mu \mathrm{M}$, the expression of P-gp decreased with the increase of CsA concentration. When the concentration of CsA was over $10 \mu \mathrm{M}$, there was a statistically significance difference in the quantity of protein expressed between the experimental groups and the control group $(\mathrm{P}<0.05, \mathrm{P}<0.01$; Figure 2$)$.

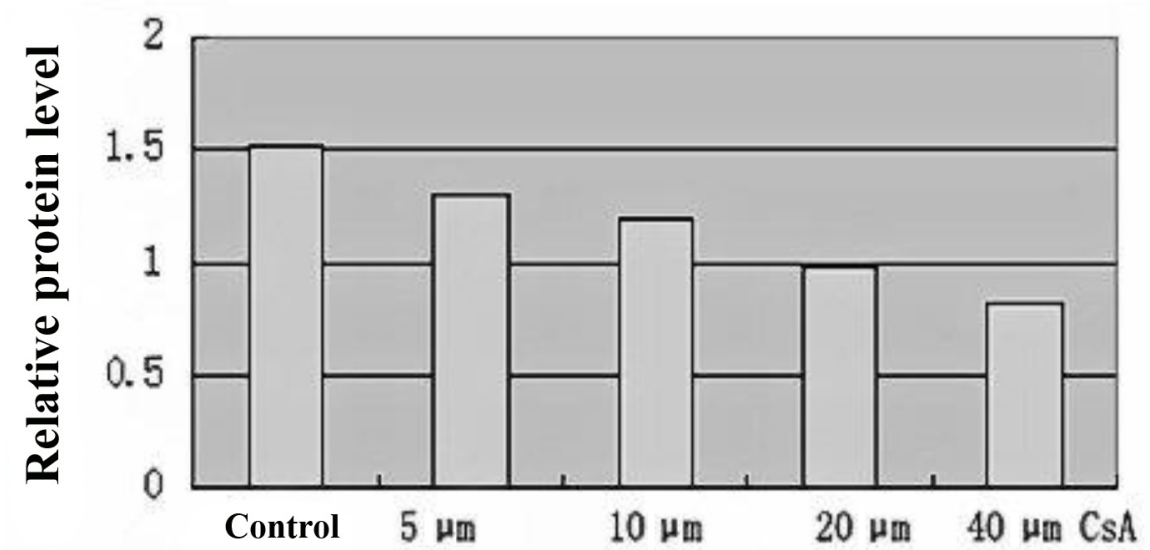

Figure 2. Influence of cyclosporin A (CsA) on expression of P-glycoprotein in gastric cancer cells.

Correlation analysis between apoptosis of gastric cancer cells induced by $\mathrm{CsA}$, and expression of P-gp in cells

The results of the Pearson correlation analysis indicated that the correlation between 
P-gp expression and the rate of apoptosis induced by CsA in late-stage gastric cancer cells and the correlation between P-gp and the total apoptosis rate were both negative. However, the correlation between P-gp expression and apoptosis rate in early-stage gastric cancer cells was not statistically significant $(\mathrm{P}=0.220)$. Therefore, we predict that the apoptosis of gastric cancer cells can be achieved by inhibiting P-gp expression.

\section{DISCUSSION}

\section{Signal pathways of apoptosis in cancer cells}

Research has indicated that the mechanism behind the molecular regulation of cell apoptosis comprises an orderly series of controlled chain reactions (Butler el al., 2003, Wieckowska et al., 2006; Laybutt et al., 2007), in which the apoptosis of cells is controlled by various genes and proteins. The verified signal pathways are mainly kinase-regulated extracellular pathways that involve death receptors and ligands, signal transduction proteins of the cytoplasm, and caspase cascade reactions, etc., and apoptotic signal pathways of the cellular mitochondria that do not depend on caspases (Yoshioka et al., 1992). Two signal pathways that center on mitochondria to regulate cell apoptosis are involved in the regulatory mechanism of cell apoptosis.

\section{Mitochondrial oxidation and cell apoptosis stress}

Mitochondria, which are often referred to as "energy factories", play an important role in cell apoptosis and energy metabolism in cells (Kopnin el al., 2004). Flow cytometry was used in this study and the results indicated that after $48 \mathrm{~h}$ of CsA treatment, large amounts of reactive oxygen species (ROS) were produced in gastric cancer cells, and the release of ROS increased with increasing CsA concentration. Moreover, the results indicate that the apoptosis pathways of mitochondria could be activated by the apoptosis of gastric cancer cells induced by CsA, which might be related to oxidative stress in mitochondria (Lei et al., 2002).

\section{Cell apoptosis and P-gp expression}

Research has indicated that drug resistance in cancers or cancer cells arises for a variety of reasons. The most common form is MDR (Kohen and Nyska, 2002), which causes a high chemotherapy failure rate in gastric cancer. In the most typical case of drug resistance, the chemotherapy drugs in the cancer cells are pumped out by the efflux pump leading to a decrease in the drug concentration in the cancer cells. The efflux pump is under the influence of transmembrane protein P-gp, which is encoded by the MDRl gene. On the basis of the correlation between P-gp expression and the degree of malignancy of the gastric cancer, the prognosis for the patients with gastric cancer can be improved by decreasing P-gp expression. Expression of P-gp in gastric cancer cells was influenced by CsA in this study, and the results showed that the expression of P-gp decreased significantly after $48 \mathrm{~h}$ of treatment with CsA. The detrimental effect of CsA on gastric cancer cells increased with increasing CsA concentration. To further investigate the relationship between P-gp expression and cell apoptosis in gastric cancer cells, we also examined the changes in cell apoptosis after CsA 
treatment. We found that $48 \mathrm{~h}$ after the end of CsA treatment, cell apoptosis also increased. Therefore, the expression of P-gp is negatively related to the apoptosis rate in cancer cells. CsA inhibits P-gp expression, thereby increasing the apoptosis rate in gastric cancer cells.

\section{CONCLUSIONS}

The process whereby CsA induces apoptosis in gastric cancer cells is multi-path and multi-target. This study shows that the molecular mechanism of the signal pathway is to decrease P-gp expression and destroy the mitochondrial outer membranes in cells. Thus, the mitochondria swell, the ROS content of the cells increases, oxidative stress is triggered in the mitochondria, and the apoptosis pathways of the mitochondria are activated.

\section{Conflicts of interest}

The authors declare no conflict of interest.

\section{REFERENCES}

Butler AE, Janson J, Bonner-Weir S, Ritzel R, et al. (2003). $\beta$-cell deficit and increased $\beta$-cell apoptosis in humans with type 2 diabetes. Diabetes 52: 102-110. http://dx.doi.org/10.2337/diabetes.52.1.102

Diestra JE, Scheffer GL, Català I, Maliepaard M, et al. (2002). Frequent expression of the multi-drug resistance-associated protein BCRP/MXR/ABCP/ABCG2 in human tumours detected by the BXP-21 monoclonal antibody in paraffinembedded material. J. Pathol. 198: 213-219. http://dx.doi.org/10.1002/path.1203

Grodzicky T and Elkon KB (2000). Apoptosis in rheumatic diseases. Am. J. Med. 108: 73-82. http://dx.doi.org/10.1016/ $\underline{\mathrm{S} 0002-9343(99) 00332-0}$

Ishizaki Y, Horiuchi S, Okuno K, Ano T, et al. (2001). Twelve hours exposure to inhomogeneous high magnetic field after logarithmic growth phase is sufficient for drastic suppression of Escherichia coli death. Bioelectrochemistry 54: 101105. http://dx.doi.org/10.1016/S1567-5394(01)00108-6

Kohen R and Nyska A (2002). Oxidation of biological systems: oxidative stress phenomena, antioxidants, redox reactions, and methods for their quantification. Toxicol. Pathol. 30: 620-650. http://dx.doi.org/10.1080/01926230290166724

Kopnin PB, Kravchenko IV, Furalyov VA, Pylev LN, et al. (2004). Cell type-specific effects of asbestos on intracellular ROS levels, DNA oxidation and G1 cell cycle checkpoint. Oncogene 23: 8834-8840. http://dx.doi.org/10.1038/ sj.onc. 1208108

Laybutt DR, Preston AM, Akerfeldt MC, Kench JG, et al. (2007). Endoplasmic reticulum stress contributes to beta cell apoptosis in type 2 diabetes. Diabetologia 50: 752-763. http://dx.doi.org/10.1007/s00125-006-0590-z

Lei K, Nimnual A, Zong WX, Kennedy NJ, et al. (2002). The Bax subfamily of Bcl2-related proteins is essential for apoptotic signal transduction by c-Jun NH(2)-terminal kinase. Mol. Cell. Biol. 22: 4929-4942. http://dx.doi. org/10.1128/MCB.22.13.4929-4942.2002

Miki J, Furusato B, Li H, Gu Y, et al. (2007). Identification of putative stem cell markers, CD133 and CXCR4, in hTERTimmortalized primary nonmalignant and malignant tumor-derived human prostate epithelial cell lines and in prostate cancer specimens. Cancer Res. 67: 3153-3161. http://dx.doi.org/10.1158/0008-5472.CAN-06-4429

Slattery C, Campbell E, McMorrow T and Ryan MP (2005). Cyclosporine A-induced renal fibrosis: a role for epithelialmesenchymal transition. Am. J. Pathol. 167: 395-407. http://dx.doi.org/10.1016/S0002-9440(10)62984-7

Sotiropoulou PA, Perez SA, Salagianni M, Baxevanis CN, et al. (2006). Characterization of the optimal culture conditions for clinical scale production of human mesenchymal stem cells. Stem Cells 24: 462-471. http://dx.doi.org/10.1634/ stemcells.2004-0331

Takeda H, Strasdine GA, Whitaker DR and Roy C (1966). Lytic enzymes in the digestive juice of Helix pomatia; chitinases and muramidases. Can. J. Biochem. 44: 509-518. http://dx.doi.org/10.1139/066-061

Wang J and Zhang Q (2001). Uptake of cyclosporine A loaded colloidal drug carriers by mouse peritoneal macrophages in vitro. Acta Pharmacol. Sin. 22: 57-61.

Wieckowska A, Zein NN, Yerian LM, Lopez AR, et al. (2006). In vivo assessment of liver cell apoptosis as a novel biomarker of disease severity in nonalcoholic fatty liver disease. Hepatology 44: 27-33. http://dx.doi.org/10.1002/hep.21223 
Wu X, Zhang W, Hayes D, Jr. and Mansour HM (2013). Physicochemical characterization and aerosol dispersion performance of organic solution advanced spray-dried cyclosporine A multifunctional particles for dry powder inhalation aerosol delivery. Int. J. Nanomedicine 8: 1269-1283.

Xiao Z, Li C, Shan J, Luo L, et al. (2011). Mechanisms of renal cell apoptosis induced by cyclosporine A: a systematic review of in vitro studies. Am. J. Nephrol. 33: 558-566. http://dx.doi.org/10.1159/000328584

Yoshioka K, Kakumu S, Wakita T, Ishikawa T, et al. (1992). Detection of hepatitis C virus by polymerase chain reaction and response to interferon-alpha therapy: relationship to genotypes of hepatitis C virus. Hepatology 16: 293-299. http://dx.doi.org/10.1002/hep.1840160203 